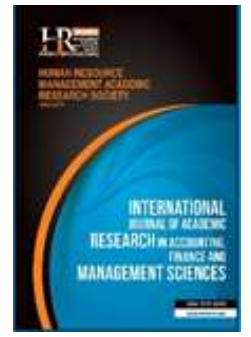

International Journal of Academic Research in Accounting, Finance and Management Sciences

Vol. 10, No.2, April 2020, pp. 49-64

E-ISSN: 2225-8329, P-ISSN: 2308-0337

(c) 2020 HRMARS

www.hrmars.com

To cite this article: Baskaran, S., Bin Kumar, S. K., Samtharam, S. R., Tangaraja, T., Mahadi, N. (2020). Home Ownership Motivation in Malaysia: A Youth Perspective, International Journal of Academic Research in Accounting Finance and Management Sciences 10 (2):49-64.

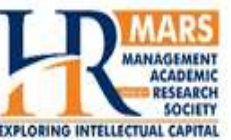

http://dx.doi.org/10.6007/IJARAFMS/v10-i2/7309

(DOI: 10.6007/IJARAFMS/v10-i2/7309)

\title{
Home Ownership Motivation in Malaysia: A Youth Perspective
}

\author{
Shathees Baskaran ${ }^{1}$, Saravin Kumar Binu Kumar², Shatish Rao Samtharam ${ }^{3}$, \\ Thanabalan Tangaraja ${ }^{4}$, Nomahaza Mahadi ${ }^{5}$ \\ 1,2,3,4,5 Azman Hashim International Business School, Universiti Teknologi Malaysia, Malaysia, \\ ${ }^{1}$ E-mail: shathees@utm.my, (Corresponding author), ${ }^{2} E$ mail: saravin13@gmail.com, \\ ${ }^{3}$ E-mail: shatishrao23@gmail.com, ${ }^{4}$ E-mail: thanabalan.t.n@gmail.com, ${ }^{5}$ E-mail: nomahaza.kl@utm.my
}

\begin{abstract}
The government of Malaysia has implemented many housing policies and programs to increase the rate of home ownership among youths. However, this rate remains low as the motivation in having a home has decreased over the years, whilst renting became the youths' alternative. Besides, a high frequency of job changing has influenced them in purchasing a house. Hence, to verify the gap, this research has performed to understand the relationship between perceived job alternatives and home ownership motivation among Malaysian youths. Local amenities investment, social capital investment, financial benefits, and residential stability are dimensions of home ownership used to study its relationship with perceived job alternatives. Whereas, job insecurity used as a mediating factor between perceived job alternatives and home ownership motivation. The research data collected through an online survey and 379 usable respondents were obtained. Results showed perceived job alternative does have a significant relationship with home ownership and its dimensions. There is also a partial mediating effect of perceived job insecurity on the relationship between perceived job alternatives and home ownership motivation. These findings will be useful for the government to understand the Malaysian youth's motivation in purchasing a house with a job being an influence.
\end{abstract}

Key words Home Ownership Motivation, Job Alternatives, Job Security, Social Capital, Youth

Received: 10 April 2020 (C) The Authors 2020

Revised: 19 May 2020 Published by Human Resource Management Academic Research Society (www.hrmars.com)

Accepted: 28 May 2020 This article is published under the Creative Commons Attribution (CC BY 4.0) license. Anyone may Published Online: 20 Jun $2020 \quad$ reproduce, distribute, translate and create derivative works of this article (for both commercial and non-commercial purposes), subject to full attribution to the original publication and authors. The full terms of this license may be seen at: http://creativecommons.org/licences/by/4.0/legalcode

\section{Introduction}

The property sector has a promising growth in Malaysia throughout recent years. The amount of supply for housing and property has drastically increased exceeding the demand. Tan (2008) supported this statement by emphasizing that since the 1980 s the housing industry has started to grow rapidly until the extent that it is encountering property oversupply in recent years. Due to this, the government was trying to increase the number of home ownership by implementing several policies to overcome the mismatch of housing supply and demand (Tan \& Khong, 2012).

However, it is difficult to cater for housing satisfaction among youths in Malaysia as many determinants are involved to increase the home ownership motivations. According to Tan (2008), employment status, housing characteristics, income trends, and demographic descriptors are the home ownership determinants that affect the motivation for an individual to own a home. Aaronson (2000) highlighted that the importance of home ownership was not taught to children from a young age which shifts their attention away from the advantages of owning a house. Home ownership is a crucial drive in improving the behavioral problems among children (Haurin et al., 2002). Youths these days are unaware of 
the importance of having a house as the source of wealth which can lead to a better future. Against all these claims, in Malaysia, home ownership motivation continuously declining and it's also due to rising prices. Malaysian Government's goal to increase the rate of home ownership. Regarding this, many establishments of housing policies and programs to cater to the needs of home for both individuals and families (Tan \& Khong, 2012). Youths in Malaysia are following the footstep of family members by not investing in housing properties. This is one of the major problems faced by the government in achieving its goal of increasing home ownership. Having said that, social attributes, financial stability, income status, job uncertainty, and awareness of the importance of owning a house are among the factors that reduce the home ownership motivation drive among youth in Malaysia (Abdullah et al., 2012).

The past study illustrated that working-class youth in Spain prefer rental as their freedom during times of crisis. The research concluded that home ownership is a significant sector in the current society but the economic condition is an import aspiration for the purchase of properties (Aramburu, 2015). Rental is a financial gateway for youths to reduce their short-term monthly commitment rather than paying a high amount for their own house for the long term. Besides this, a study was conducted on how home ownership affects the health of an individual compared to those who rent a house. The research highlighted that those who own a house are likely to have a lower level of depression and stress than those who are renting (Evans et al., 2001). This is because there is no sense of security and ownership in rental houses which leads to physiological distress. A sense of ownership can only be attained when the house is purchased. However, in Malaysia, mid-incomer requires a longer stretch to own a house (Tan, 2008). Longer time for an individual to work towards owning a house is the main reason for the decrease in home ownership motivation. The financial instability of these mid-income groups due to their occupations slows the process of owning the house. Households should only spend about $30 \%$ of their income to pay their house and utilities (Baqutaya et al., 2016). Paying more than 30\% of their income is burdening to the families to sustain for the long term. Due to high housing prices, the lower and middle-income groups are unable to purchase houses as they need to spend more than $30 \%$ of their income to own a house. This is one of the reasons why income plays a crucial role in determining an individual to own a house.

Therefore, the purpose of this research is to examine perceived job alternatives among youths in Malaysia which affects the home ownership motivation with perceived job insecurity being the mediating factor. Thus, the following are the research questions of this research. More specifically, the research aims to (1) investigate the relationship between perceived job alternatives and home ownership motivation (and its corresponding dimensions) and (2) investigate the mediating effect of perceived job insecurity on the relationship between perceived job alternatives and home ownership motivation.

\section{Literature review}

\subsection{Malaysian Youth and Homeownership}

Recent studies showed home ownership has decreased among youth in Malaysia due to affordability. A recent study by Shoed \& Subramaniam (2016) found that drastic escalation of house prices has decreased the affordability of purchasing a house among generation $\mathrm{Y}$. Hence, rising prices indicated that there were continuous pressures to ensure sustainable income sources before making home ownership decisions. This issue was investigated by Mostafa et al. (2006) who pointed out that housing affordability requires a stable income to sustain throughout their payment period. Whereas, Zan \& Yue (2008) concluded that affordability is not just the price of the house but the earnings of the respective individual to sustain paying it for the long term. Since every nation is vulnerable to change in socio-economic conditions, Malaysia is no exception. On this ground, Abd Aziz et al. (2011) summarized that the housing affordability of Malaysia can portray the country's socio-economic stability. Therefore, it is said that job alternatives and job insecurity play important roles in maintaining a stable and sustainable income to ensure that youths can afford a house.

\subsection{Home Ownership Motivation}

Home ownership motivation is the motivation to drive an individual to purchase a home compared to renting one. A study showed that home ownership is one of the factors to contribute to housing satisfaction (Tan \& Khong, 2012). This was based on Rossi and Weber (1996) which stated that 
homeowners having higher housing satisfaction compared to the ones who are renting homes. Home ownership satisfies a wide range of household needs. Households are likely to be allocated where there is the convenience of facilities and a good neighborhood. Urban-rural migrants in the United States whose rents are motivated to shift in becoming owners due to the satisfaction of owning a house (Barcus, 2004). This is because home ownership provides a sense of control over the house. Owners can design and renovate the house according to their wishes (Lu, 2002). Rohe et al. (2013) stated that home ownership is another motivating factor that brings out a sense of achievement in an individual. Individuals use to feel their achievement once they have a place of their own to stay. Moreover, the environment of a rental house is not convenient for a child's development as the physical condition of the house might be poor (Harkness \& Newman, 2003). This will drive individuals to have higher home ownership motivation to ensure their children will get a better living environment. A study by Haven, Wolfe \&Spauding (1991) explained that staying in a rental house will cause a higher possibility of moving out based on the tenant agreement. It was further strengthened by another study, explaining that homeowners move lesser than those renters (Yun \& Evangelou, 2016). This provides them with a higher housing satisfaction as they are embedded with the neighborhood that they are comfortable with.

\subsubsection{Local Amenities Investment}

Local amenities investment is a good factor for every individual to invest in houses which increases the motivation of home ownership. It helps in maintaining stability in the neighborhood. Residents have focused on investing in local amenities to have convenience throughout their stay. Saiz (2010) emphasized that residential area which has high amenity are likely to be risky in terms of money but expectations are relatively good. Home owners in a residential area usually participate with their neighbors informally through their local organization (Di Pasquale \& Glaeser, 1999). Residents have such an informal organization to have a good relationship among them. Another reason for such an organization is to be secure from external threats which can cause the safety of the residents being jeopardized. Internal threats such as poor maintenance also can be overcome with such organizations in the residential area (Tan, 2008). The perception of implementing local amenities among homeowners is different compared to those renters. Renter will not involve much in these local amenities because they don't have a sense of ownership to ensure that all the facilities are in good condition. Moreover, with all this investment on local amenities, it may increase the price of a house in the area as it is well maintained with good facilities. Home owners promote stability in the neighborhood through local amenities investment. So, it's proven that local amenities investment is a good factor contributing to home ownership motivation.

\subsubsection{Social Capital Investment}

Social capital is defined as a social network that was created by the participant in the purpose of delivering and distributing information to have a medium of communication (Westlund, 2006). Another study defined that social interactions is created with an establishment of social capital investment (Bolin et al., 2003). This is a very significant aspect that can be established to increase home ownership motivation among people. Investment as such will benefit the residential as it allows them to maintain an effective communication link among their neighbors. A study in Spain showed that social interaction has become one of the criteria for homeowners to evaluate housing satisfaction (Vera-Toscana \& Alteca-Amestoy, 2008). Rohe \& Stegman (1994) explained that social connection is very useful for homeowners as it can build up self-esteem among them. Homeowners have larger incentives compared to renter when they invest in social capital. The renter can also benefit from these incentives if they stay for a long period which must exceed their initial investment (Hilber, 2017). Incentives form social capital encourages renters to own their own home to have better benefits. Kan (2007) articulated that residents tend to stay long as they feel supported by the social network that was build up. Harness \& Newman (2003) highlighted beside the residents, children who are brought up in their own homes will achieve good grades in school as social capital grows. Children will have a better education as parents can support them financially with the help of social capital investment. Investment in social capital establishes good social interactions within neighbors which increase the value of the houses due to high home ownership motivation (Bolin et al., 2003). 


\subsubsection{Financial Benefits}

Investing in houses is a source of a good investment for an individual as it can bring a positive financial return in upcoming years (Tan, 2008). A study conducted in Australia stated that investing in housing property is one of the reliable personal investments, as house values seldom depreciate over the years (Badcock \& Beer, 2000). Although it is beneficial to own a house, another point that can lead to higher financial benefit is the location of the house being bought (Belsky \& Duda, 2002). For example, houses in Kuala Lumpur have risen about $35 \%$ in 2010 which is a very good investment for those who have invested a few years back (Shoed \& Subramaniam, 2016). Study shows that investing in property especially houses will aid in having higher returns compared to bonds (Goetzmann, 1993). The demand for property is always in the market and there is less possibility for the prices to drop drastically. Besides that, overall the mortgage interest can be deducted in a huge amount once huge payments are done to clear the loan (Herbert \& Belsky, 2008). This helps in saving more as the amount paid will like be lesser than the actual amount paying over the years. Home ownership has an advantage as investing in a house is a barrier toward inflation (Goetzmann \& Spiegel, 2000). Moreover, it is a low-risk investment by investing in houses, the return rate of this investment is relatively high compared to stock and other currencies (Masron \& Fereidouni, 2010). It is a good source of investment which can bring positive returns down the years (Tan, 2008). Houses provide high returns compared to bonds which will aid during difficult times (Goetzmann, 1993).

\subsubsection{Residential Stability}

Rohe \& Steward (1996) defined that residential satisfaction comprises both the house and surrounding residents. The longer period of stay at the respective neighbor will bring out a positive relationship towards home ownership. Another research found that home ownership motivation can be increased when the people around the neighborhood are helpful and friendly (Savasdisara et al., 1989). Friendly and helpful neighbors will create a sense of security and satisfaction among residents as they believe there are people around them during times of emergencies. Another research also proved that residents are satisfied when their home is surrounded by friendly residents (Rohe \& Steward, 1996). On the other hand, Salleh (2008) stated that residential stability does not only rely on the people in the neighborhood but also the facilities that can be delivered to the house owner. Good facilities such as educational facilities, security services, transportation, and central facilities will increase the motivation of people to own a house in that neighborhood. Overall, residentially stability is a great source to improve children's education outcomes as well (Haurin et al., 2002). Children will feel comfortable and able to concentrate on their studies with a good environment when there is good residential stability. Children's outcome on residential stability was further studied by Lien et al. (2008) emphasizing that children do not face any problems adapting to new social networks when there is residential stability in the neighborhood. Aarosons (2000) also proved that residential stability has relatively high positive impacts on school graduates due to their comfort in the environment. Children perform at most in both studies and lifestyle when there is residential stability in the neighborhood (Lien et al., 2008).

\subsection{Job Alternatives}

Perceived job alternatives are a movement of an individual from one job to another better job opportunity which satisfies them (Rabbi et al., 2015). Perceive job alternatives do not only affect the organization's turnover but it also emphasizes the individual's turnover intention where they voluntarily leave their current job to seek a better opportunity (Rojanasarot et al., 2017). An example illustrated by Griffeth et al., (2000), stated that in the pharmaceutical approach, pharmacists having a higher possibility of leaving their job to further improve their career growth. Besides that, studies show that another step in overcoming job dissatisfaction is an alternative job opportunity (Hulin et al., 1985). Dissatisfaction on the current job that drives an individual to seek for an alternative job in hoping to have a better working environment to sustain for a long term. Job alternatives can influence an individual by the offers provided such as high pay and benefits (Price, 2001). In other words, low job alternatives for an employee can boost their current job satisfaction and increase their performance in doing better to attain high rewards in terms 
of monetary (Laker, 2011). According to Sheahan (2008), throughout the Asian Pacific Region, Generation- $Y$ having the shortest term in retaining a job compared to other generations. Besides, youth in the context of Malaysia have been frequently changing jobs due to dissatisfaction (Queiri et al., 2015). Youth these days are more focusing on the amount of money that can be earned rather than achieving high performance. They tend to be dissatisfied with their current pay and benefits, working environment, work-life balance, and availability of alternative jobs which leads them to change their job frequently. Moreover, according to Der Hovanesian (1999), Generation-Y spends more on consumer goods and personal services rather than investing them. Khatri et al. (2001), also stated that youth does not solely rely on better job alternatives but they do change job due to personal characteristics and social influence. Movement from one job to another with low income hinders an individual to pay such a huge commitment for a housing loan. Youth does not have the motivation of owning a house as their spending power for personal services will be affected. Frequency of changing jobs frequently can influence an individual in attaining property commitment as they are not financially stable to purchase houses with a higher price (Treuren, 2013).

\subsection{Perceived Job Insecurity as Mediator}

Perceived job insecurity is known as a job being at threat where an individual's fear of losing a respective job (Hellgren \& Sverke, 2003). According to the statement by Naswall et al. (2005) the nature of work that is often changing causes job insecurity to increase globally. The performance of an individual can be influenced drastically due to the insecurity of the job (Yusoff et al., 2017). Individuals tend to have the fear of losing their job-creating an inability to concentrate on their current job hence affecting their performance. Campbell \& Sengenberger (1994) highlighted that job insecurity can determine the well-being of an individual from various perspectives. It further explains that the lifestyle and health of the individual can be determined by the status of current job security. Another study explained that gender attributes do have an impact on job insecurity. This was further confirmed as Kinnunen et al. (1999) saying that men have high levels of job insecurity compared to women. Men having a higher possibility of a threat to job loss which can deteriorate their motivation as they are the breadwinner of the family (De Witte, 1999). Job uncertainty plays a vital role in the well-being of a family (Larson et al., 1994). Family financial status will be jeopardized when an individual loses the job. Besides, job security is a major factor that leads to job satisfaction. Research has shown that job insecurity does not only focus on the ability to lose a job but it can be viewed in certain dimensions of the job (Klug, 2017). Short terms laid off, growth and promotions being cut off and salary cut off are the key dimensions of job insecurity (Kalleberg, 2000). Youths are more likely to experience job insecurity in an organization as most of them are on a contract basis. Gebel (2010) articulated that lower educated employees working in a low-quality job having higher uncertainty in sustaining long. Moreover, youths having a short period of experience are the ones being laid off during an economic crisis compared to those who are working for many years (Scarpetta et al., 2010). Job insecurity will lead an individual to search for other job alternatives to have permanent financial stability. Job insecurity influences an individual to not invest in assets as their financial status will be jeopardized when an individual loses the job. Affordability of owning a house does not only depend on the price but longterm payment which an individual with job insecurity unable to sustain for the long term (Zan \& Yue, 2008).

\subsection{Research Model and Hypotheses}

The theoretical framework of this study provided further insights for a conceptual framework to indicate the possible relationship between perceived job alternatives and home ownership motivation among youth. Perceived job insecurity is represented as a mediating effect on the relationship between both perceived job alternatives and home ownership motivation. Four factors contributed to home ownership motivation which are local amenities investment, social capital investment, financial benefits, and residential stability. The given framework below used to investigate how the overall job can play a major role in influencing youths in Malaysia to own a house. Based on the discussions above, the following hypotheses were formulated:

$\mathrm{H} 1$ There is a significant relationship between perceived job alternatives and home ownership motivation. 
$\mathrm{H} 1 \mathrm{a}$ There is a significant relationship between perceived job alternatives and home ownership motivation (local amenities investment).

$\mathrm{H} 1 \mathrm{~b}$ There is a significant relationship between perceived job alternatives and home ownership motivation (social capital investment)

$\mathrm{H} 1 \mathrm{c}$ There is a significant relationship between perceived job alternatives and home ownership motivation (financial benefits).

$\mathrm{H} 1 \mathrm{~d}$ There is a significant relationship between perceived job alternatives and home ownership motivation (residential stability).

$\mathrm{H} 2$ There is a mediating effect of perceived job insecurity on the relationship between perceived job alternatives and homeownership motivation.

A theoretical framework as shown in Figure 1 was proposed in this study to test these relationships. Framework as shown below.

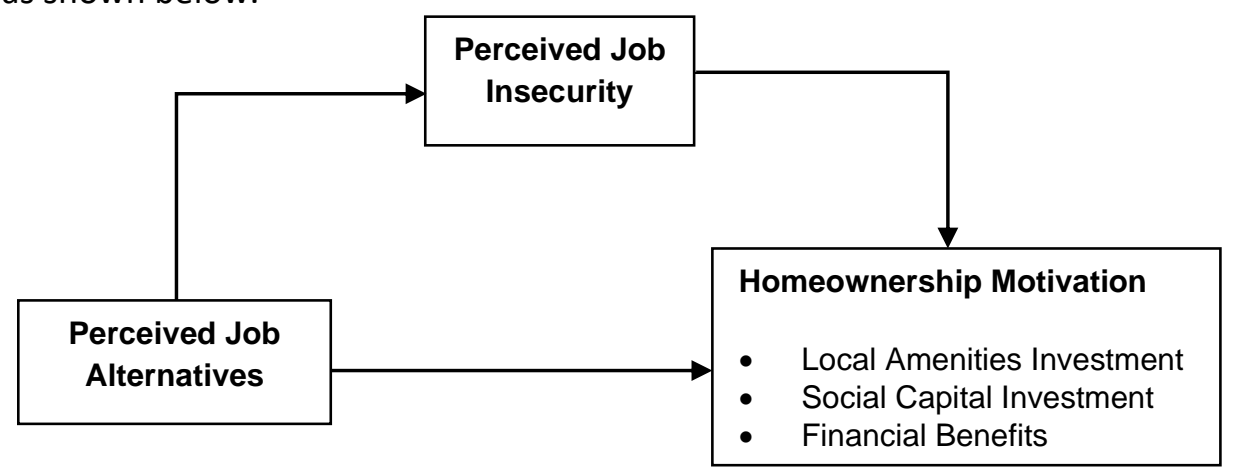

Figure 1. Research Model

\section{Methodology of research}

\subsection{Sample and Data Collection}

This research focuses on the home ownership motivation that Malaysian youth possess. Therefore, the sample size required for this research would consist of Malaysian youths from the age group of 20 to 40 years old as in line with the National Youth Development Policy of Malaysia. Research covers every region throughout Malaysia which includes all the states and cities. The study requires a minimum sample size of 384 respondents (Krejcie \& Morgan, 1970). A convenience sampling technique has used in this research. This is a nonrandom sampling method to reach the targeted population based on availability, accessibility, and reasonable cost (Dornyei, 2013). Data collection in this research has focused on the quantitative method where the data for this research is collected through online survey questionnaires. Data collection consumed three months to attain the required number of respondents. The questionnaires consist of four sections which are sections $A, B, C$, and $D$. For section $A$ would contained general questions related to the respondents' details, section $B$ focused on perceived job alternatives, section $C$ covered on home ownership motivation and lastly, Section D was about perceived job insecurity.

\subsection{Measures and Instrumentation}

The measurement used for this research is a nominal and 5-point Likert scale. The answer choices for the 5-point Likert scale are (strongly disagree -1 ), (disagree -2 ), (neutral -3 ), (agree -4 ), and (strongly agree - 5) (Wolfer, 2007). Collected data provides further insights on the perceived job alternative having a relationship with home ownership motivation. Instrumentation for this research was adapted from past studies questionnaires. The questionnaire items for this research's variable and its dimensions are as stated in Table 1. 
Table 1. Research Test Instruments

\begin{tabular}{|l|l|l|l|}
\hline \multicolumn{1}{|c|}{ Author } & \multicolumn{1}{|c|}{ Construct } & \multicolumn{1}{|c|}{ Dimensions } & Number of Items \\
\hline \multirow{3}{*}{ Tan (2008) } & Home Ownership Motivation & Local Amenities Investment & 4 \\
\cline { 3 - 4 } & & Social Capital Investment & 7 \\
\cline { 3 - 4 } & & Financial Benefits & 6 \\
\cline { 3 - 4 } & Residential Stability & 3 \\
\hline Treuren (2013) & Perceived Job Alternatives & N/A & 5 \\
\hline Borg \& Elizur (1992) & Perceived Job Insecurity & N/A & 4 \\
\hline
\end{tabular}

\section{Data Analysis and Results}

\subsection{Research Sample Analysis}

A total of 379 respondents participated in this study. Based on the data collected, a research sample analysis was performed and the results are shown in Table 2:

Table 2. Research Sample Analysis

\begin{tabular}{|l|c|c|c|}
\hline \multicolumn{1}{|c|}{ Characteristics } & Category & Frequency & (\%) \\
\hline Gender & Male & 191 & 50.4 \\
\hline & Female & 188 & 49.6 \\
\hline Work Experience & $0-5$ years & 314 & 82.8 \\
\hline & $6-10$ years & 53 & 14.0 \\
\hline & $11-15$ years & 6 & 1.6 \\
\hline & $16-20$ years & 4 & 1.1 \\
\hline Monthly Income & $21-25$ years & 2 & 0.5 \\
\hline & Below RM 2000 & 76 & 20.1 \\
\hline & RM 2001- RM 4000 & 201 & 53.0 \\
\hline & RM 4001- RM 6000 & 71 & 18.7 \\
\hline & RM 6001- RM 8000 & 20 & 5.3 \\
\hline & $>$ RM 8000 & 11 & 2.9 \\
\hline
\end{tabular}

Based on Table 2, the total of 191 respondents is male while 188 are female making a total of 379 respondents. Besides that, 314 respondents are having 0-5 years of working experiences followed by 53 respondents having 6-10 years, 6 respondents having 11-15 years, 4 respondents having $16-20$ years, and 2 respondents having 21-25 years. Moreover, the table also shows that 76 respondents are having a monthly income below RM2000, 201 respondents having RM2001-RM4000, 71 respondents having RM4001RM6000, 20 respondents having RM6001-RM8000, and 11 having above RM8000.

\subsection{Research Instruments Reliability}

Reliability analysis is aimed to analyze the reliability of the constructs used in the study. The common estimate used in research is the Cronbach Coefficient Alpha $(\alpha)$ which is used to calculate the average splithalf reliability for a multiple-item scale. The reliability of this test has a coefficient that varies from 0 to 1 (Malhotra, 2007). A value of 0.6 and above illustrates that the internal consistency reliability is satisfactory (Malhotra, 2004). The following are the results of the test conducted.

Table 3. Research Instrument Reliability

\begin{tabular}{|l|c|}
\hline \multicolumn{1}{|c|}{ Construct } & Cronbach's Alpha \\
\hline Local Amenities Investment (HOL) & 0.833 \\
\hline Social Capital Investment (HOS) & 0.892 \\
\hline Financial Benefits (HOF) & 0.875 \\
\hline Residential Stability (HOR) & 0.763 \\
\hline Perceived Job Alternatives (PJA) & 0.777 \\
\hline Perceived Job Insecurity (PJI) & 0.839 \\
\hline
\end{tabular}


The results in Table 3 indicate that all constructs have achieved a Cronbach alpha value of more than 0.7 threshold level confirming the internal consistency of the constructs.

\subsection{Exploratory Factor Analysis (EFA)}

Bartlett's Test Sphericity and Kaiser-Mayer-Olkin (KMO) are commonly used tests to evaluate factorial analysis adequacy. Kaiser-Meyer-Olkin (KMO) test is carried out to measure the sampling adequacy of this study. The KMO value greater than 0.5 indicates that the sample is adequate (Thompson, 2004). A KMO value of more than 0.5 is acceptable even if mediocre. However, a KMO value closer to 1 is desirable. Bartlett's test of Sphericity is used in testing the presence of the identity matrix hypothesis. This presence can be checked through the significant interrelationship that exists between variables (Field, 2009). The results of both tests are presented in Table 4:

Table 4. Measure of Sampling Adequacy

KMO and Bartlett's Test

\begin{tabular}{|l|c|c|}
\hline \multicolumn{2}{|l|}{ Kaiser-Meyer-Olkin Measure of Sampling Adequacy } & .845 \\
\hline Bartlett's Test of Sphericity & Approx. Chi-Square & 5959.453 \\
\hline & df & 435 \\
\hline & Sig. & .000 \\
\hline
\end{tabular}

Based on Table 4, the KMO test shows that it is adequate (i.e. 0.845 which is higher than 0.5). The null hypothesis is rejected as Bartlett's test significance value is 0.000 which is less than 0.05 . Since both tests met the requirements, a principal component analysis was performed and the results are shown in Table 5:

Table 5. Total Variance Explained - Home Ownership Motivation

\begin{tabular}{|c|c|c|c|c|c|c|c|c|c|}
\hline \multirow[b]{2}{*}{ Component } & \multicolumn{3}{|c|}{ Initial Eigenvalues } & \multicolumn{3}{|c|}{ Extraction Sums of Squared Loadings } & \multicolumn{3}{|c|}{ Rotation Sums of Squared Loadings } \\
\hline & Total & $\%$ of Variance & Cumulative \% & Total & $\%$ of Variance & Cumulative \% & Total & $\%$ of Variance & Cumulative \% \\
\hline 1 & 6.397 & 31.986 & 31.986 & 6.397 & 31.986 & 31.986 & 3.989 & 19.944 & 19.944 \\
\hline 2 & 3.527 & 17.636 & 49.622 & 3.527 & 17.636 & 49.622 & 3.761 & 18.807 & 38.751 \\
\hline 3 & 1.961 & 9.804 & 59.426 & 1.961 & 9.804 & 59.426 & 3.235 & 16.177 & 54.928 \\
\hline 4 & 1.299 & 6.496 & 65.922 & 1.299 & 6.496 & 65.922 & 2.199 & 10.994 & 65.922 \\
\hline 5 & .950 & 4.750 & 70.672 & & & & & & \\
\hline 6 & .790 & 3.949 & 74.621 & & & & & & \\
\hline 7 & .751 & 3.756 & 78.377 & & & & & & \\
\hline 8 & .636 & 3.182 & 81.559 & & & & & & \\
\hline 9 & .547 & 2.737 & 84.297 & & & & & & \\
\hline 10 & .437 & 2.185 & 86.482 & & & & & & \\
\hline 11 & .409 & 2.045 & 88.527 & & & & & & \\
\hline 12 & .380 & 1.902 & 90.429 & & & & & & \\
\hline 13 & .327 & 1.634 & 92.063 & & & & & & \\
\hline 14 & .301 & 1.507 & 93.570 & & & & & & \\
\hline 15 & .285 & 1.427 & 94.998 & & & & & & \\
\hline 16 & .273 & 1.364 & 96.362 & & & & & & \\
\hline 17 & .244 & 1.218 & 97.579 & & & & & & \\
\hline 18 & .231 & 1.155 & 98.734 & & & & & & \\
\hline 19 & .130 & .651 & 99.385 & & & & & & \\
\hline 20 & .123 & .615 & 100.000 & & & & & & \\
\hline
\end{tabular}

Component 1: HOS, 2-HOF, 3-HOL, 4-HOR

Through factorial analysis, as expected, four principal factors were identified with an eigenvalue above 1 . These four factors explained 65.922 percent variance. The results for each factor in sequential 
order, are as follows: Social Capital Investment (HOS), Financial Benefits (HOF), Local Amenities Investment (HOL) and Residential Stability (HOR). The rest of the factors were discarded from further examination.

Table 6. Rotated Component Matrix - Home Ownership Motivation

Construct

Items

Factor Loading

\begin{tabular}{llll}
\hline Local Amenities & HOL1. & I have participated in local community projects. & .611 \\
& HOL2. & I am a member of a residential association. & .812 \\
& HOL3. & I contribute time and effort to improve my neighborhood. & .835 \\
Social & HOL4. & I involve in local improvement groups in my neighborhood. & .881 \\
Investment & HOS1. & I socialize with my neighbours. & .777 \\
& HOS2. & My neighbours are friendly. & .878 \\
& HOS3. & My neighbors are helpful. & .885 \\
& HOS4. & My neighbors look after my property when I am away. & .792 \\
& HOS5. & I spend an evening out with my neighbours. & .566 \\
& HOS6. & I enjoy gardening with my neighbours. & .600 \\
Financial Benefits & HOS7. & My neighbours are members of a residential association. & .777 \\
& HOF1. & Property has the potential for income gains. & .760 \\
& HOF2. & Property has the potential for capital gains. & .792 \\
& HOF3. & Property is a good investment to hedge against inflation. & .841 \\
& HOF4. & Property is a good investment for retirement. & .826 \\
& HOF5. & Property is a good investment for children's education. & .775 \\
& HOF6. & Property is a major source of wealth. & .702 \\
& HOR1. & I stay in the neighborhood longer due to my neighbors. & .716 \\
\cline { 2 - 3 } Residential Stability & HOR2. & I stay in the neighborhood longer due to amenities. & .816 \\
& HOR3. & I stay in the neighborhood longer due to high relocation costs. & .708
\end{tabular}

The results of rotated factor loadings for Home Ownership Motivation are shown in Table 6 above. EFA results indicated a factor loadings range between 0.600 and 0.885 . Since the loadings were above 0.32 as suggested by Tabachnick \& Fidell (2014), all items were retained for further analysis.

Table 7. Total Variance Explained - Perceived Job Alternatives

\begin{tabular}{|c|c|c|c|c|c|c|}
\hline & \multicolumn{3}{|l|}{ Initial Eigenvalues } & \multicolumn{3}{|c|}{ Extraction Sums of Squared Loadings } \\
\hline Component & Total & $\%$ of Variance & Cumulative \% & Total & \% of Variance & Cumulative \% \\
\hline 1 & 2.668 & 53.355 & 53.355 & 2.668 & 53.355 & 53.355 \\
\hline 2 & .700 & 13.998 & 67.354 & & & \\
\hline 3 & .679 & 13.587 & 80.941 & & & \\
\hline 4 & .537 & 10.733 & 91.674 & & & \\
\hline 5 & .416 & 8.326 & 100.000 & & & \\
\hline
\end{tabular}

The ANOVA was performed for Perceived Job Alternatives. The results provided adequate evidence for the unidimensionality of the construct by resulting in only one valid component. The cumulative variability explained in the extracted solution accounted for 53.355 percent.

Table 8. Component Matrix - Perceived Job Alternatives

Construct

Perceived Job Alternatives
Items

PJA1. I could easily find another job.

PJA2. I could easily find a better job than the one I now have.

PJA3. I could easily find a similar job somewhere else.

PJA4. I know of several job alternatives that I could apply for.

PJA5. I have actual job offers in hand.
Factor Loading 
Table 8 shows the result of the rotated factor loadings for each component. All items considered resulted in a factor loading above required threshold levels. The factor loadings ranged between 0.648 and 0.809. All items were retained for subsequent analysis.

Table 9. Total Variance Explained - Perceived Job Insecurity

\begin{tabular}{|c|c|c|c|c|c|c|}
\hline & \multicolumn{3}{|c|}{ Initial Eigenvalues } & \multicolumn{3}{c|}{ Extraction Sums of Squared Loadings } \\
\hline Component & Total & \% of Variance & Cumulative \% & Total & \% of Variance & Cumulative \% \\
\hline 1 & 2.709 & 67.713 & 67.713 & 2.709 & 67.713 & 67.713 \\
\hline 2 & .544 & 13.592 & 81.305 & & & \\
\hline 3 & .391 & 9.768 & 91.073 & & & \\
\hline 4 & .357 & 8.927 & 100.000 & & & \\
\hline
\end{tabular}

An ANOVA was performed to analyze the total variance explained for Perceived Job Insecurity. The result indicated that this construct is a unidimensional construct with only one factor (where the Eigenvalue was more than 1.0). This single factor accounted for 67.713 percent of the variance in explaining this construct.

Table 10. Component Matrix - Perceived Job Insecurity

Construct Items

Factor Loading

\begin{tabular}{llll}
\hline Perceived Job Insecurity & PJI1. I believe that my job in this organization is secure. & .836
\end{tabular}

PJI2. In my opinion, I will have a job in this organization for as long as I $\quad .827$

want one.

PJI3. I am confident that this organization will continue to need my skills and job knowledge.

PJI4. My job performance history will protect me from losing my job in this organization.

EFA was performed for Perceived Job Insecurity. The results are provided in Table 10. All items were reporting strong loadings with a minimum loading of 0.791 (i.e. item PJI4) and a maximum loading of 0.837 (i.e. item PJI3). Hence, all items were retained for hypotheses testing.

\subsection{Hypotheses Testing}

An analysis was conducted to assess path coefficient significance. The path diagram and the relationship between endogenous and exogenous variables considered in the study are shown in Figure 2 below. The results of path coefficients are shown in Table 11.

Table 11. Standardized Regression Weights Based on Fit Model

\begin{tabular}{cccccccc} 
Hypothesis & Endogenous & & Exogenous & Std. Estimate & $t$-value & P-Value & Decision at $p<0.05$ \\
\hline H1 & HOM & $\leftarrow$ & PJA & 0.181 & 3.581 & 0.000 & Significant \\
H1a & HOL & $\leftarrow$ & PJA & 0.183 & 3.610 & 0.000 & Significant \\
H1b & HOS & $\leftarrow$ & PJA & 0.149 & 2.919 & 0.004 & Significant \\
H1c & HOF & $\leftarrow$ & PJA & 0.013 & 0.252 & 0.801 & Not Significant \\
H1d & HOR & $\leftarrow$ & PJA & 0.171 & 3.368 & 0.001 & Significant \\
\hline
\end{tabular}

The results of path coefficients for direct relationships are shown in Table 11. Based on the results obtained, 4 out of 5 hypotheses tested were supported.

In testing for the relationship of two or more variables with mediating factor, a test proposed by Baron \& Kenny (1986) was performed. It suggested the four-step approach of regression analysis to determine the significance of the coefficients derived at each respective step. The first three steps are to identify that there is a zero-order relationship among the tested variables. Once all three steps show a significant relationship, step four can proceed. If any of the steps from step one to step three become insignificant, it can be concluded to be no mediation (Mackinnon et al., 2007). For step four, partial 
mediation is supported if the mediating factor perceived job insecurity remains significant after controlling the independent variable, home ownership motivation.

Based on Table 12, the first three steps found to be significant as $p<0.05$ and have allowed continuing with step 4, mediating test. In step four, both perceived job alternatives and perceived job insecurity remain significant, $p$-value $<0.05$ which concludes that partial mediation of perceived job insecurity exists on the relationship between perceived job availability and home ownership motivation.

Table 12. Mediation Analysis

\begin{tabular}{cccccccc} 
Step & Endogenous & & Exogenous & Std. Estimate & $t$-value & P-Value & Decision at $p<0.05$ \\
\hline 1 & HOM & $\leftarrow$ & PJA & 0.181 & 3.581 & 0.000 & Significant \\
2 & PJI & $\leftarrow$ & PJA & -0.152 & -2.990 & 0.003 & Significant \\
3 & HOM & $\leftarrow$ & PJI & -0.270 & -5.445 & 0.000 & Significant \\
4 & HOF & $\leftarrow$ & PJA \& PJI & 0.144 & 2.890 & 0.004 & Significant \\
& & & & -0.248 & -4.994 & 0.000 & Significant \\
\hline
\end{tabular}

\section{Discussions and Conclusions}

This study explored the relationship between perceived job alternatives and home ownership motivation as well as determining the mediating effect of perceived job insecurity among Malaysian youth. The findings have shown that three out of the four factors contributing to home ownership which are local amenities investment, social capital investment, and residential stability have a significant relationship with perceived job alternatives. Whereas, financial benefits do not have a significant relationship with perceived job alternatives. Meanwhile, the mediating effect of perceived job insecurity has a significant relationship between perceived job alternatives and home ownership motivation.

According to Munch et al. (2008), home owners are less likely to change jobs as they are less mobile compared to the renter. Oswald (1997) emphasized that changing jobs or unemployment decreases the motivation for home ownership as they need to be mobile to search for new jobs. This strengthens the relationship between job alternatives and home ownership motivation. The findings of this research indicated that the frequency of changing job influences home ownership motivation due to local amenities investments. This is in line with Clark et al. (2006), claiming another important factor in home ownership motivation is by looking at local amenities surrounding the housing area which reduces the likelihood of changing jobs. This statement was also strengthened by Krasten (2007), stating with local amenities investment, the workplace might be a closer distance to home which increases the motivation in owning the house. The significant relationship between perceived job alternatives and social capital investment has been explored and proved by other researchers as well. Kan (2007) proves that social capital investment has an impact on perceived job alternatives as it promotes individuals to stay there permanently due to good neighborhood cohesion. Individuals do not change jobs where they need to move out as they derive financial and emotional supports from their social network (Krasten, 2007). This strengthens the relationship between perceived job alternative and social capital investment. The findings of this research indicated that the frequency of changing jobs does not influence home ownership motivation due to financial benefits. According to Lim (2013), the property market is affected due to the upward revision of Real Property Gain Tax (RPGT) where it does not provide financial benefits in owning a house. Affordability is a major factor in purchasing a house (Karsten, 2007). Changing jobs frequently do not influence the affordability of an individual in purchasing a house which would not benefit them financially. Because of limited research studies regarding this relationship, more results might be required in the future to improve and support the validity of the findings. The findings from this study indicated that perceived job insecurity exists partially on how perceived job alternatives affected home ownership motivation. This is aligned with the findings by Kupke (2003), indicated that a lack of job security is more substantial in driving changes in the behavior of first time home buyers. Beer (2011) mentioned that all organization's measures likely to fuel job insecurity and place pressures on employees to modify their job and seek alternative employment. Furthermore, Beer (2011) stated that perceived job alternatives are a result of perceived job insecurity which Kupke (2003) on the contrary stated it influences the motivation in owning a house. Therefore, it can 
be concluded that perceived job insecurity has a partial mediating factor on perceived job alternatives and home ownership motivation.

In terms of theoretical contribution, this research contributed to provide clear information on the Malaysian's youth motivation in owning a house. This study gives further insights into the factors contributing to home ownership motivation. It also provides researchers a better understanding of the linkage of perceived job alternatives with home ownership motivation. These linkages were tested and additional knowledge about perceived job alternatives and home ownership motivation from the findings recently developed. Moreover, the positive results on perceived job insecurity as a mediator effect on perceived job alternatives and home ownership motivation given a new knowledge towards understanding youth motivation in owning a house. Lastly, results from this study could be used to develop a new theoretical framework in future studies.

In terms of managerial contribution, the finding from this study could be used by the government as their national housing policy is to increase the number of home ownership motivations. It will give the government insight into developing a better understanding of youth's behavior in owning a house. The findings of this study are significant in providing a better understanding of the relationship between perceived job alternatives and home ownership motivation as a tool to evaluate how job influences the decision of youth to purchase a house. This study also allows housing developers to understand the drivers that motivate youth to own a house. For instance, developers can invest in local amenities investment and social capital to attract Malaysian youths in purchasing the houses.

\section{References}

1. Aaronson, D. (2000). A Note on the Benefits of Homeownership. Journal of Urban Economics, Vol. 47(3), pp. 356-369.

2. Abdullah, L., Nor, S. I. B. M., Jumadi, S. N., \& Arshad, S. H. (2012). First-time home buyers: Factors influencing decision making. In International Conference on Innovation and Technology for Sustainable Built Environment, (pp. 249-254).

3. Aramburu, M. (2015). Rental as A Taste of Freedom: The Decline of Home Ownership amongst Working-class Youth in Spain during Times of Crisis. International Journal of Urban and Regional Research, Vol. 39(6), pp. 1172-1190

4. Arshad, M., Farooq, O., \& Farooq, M. (2019). The effect of intrinsic and extrinsic factors on entrepreneurial intentions: The moderating role of collectivist orientation. Management Decision, 57(3), 649-668.

5. Aziz, W. N. A. W. A., Hanif, N. R., \& Singaravello, K. (2011). Affordable housing within the middle income households in Malaysia: Challenge to enter homeownership. Australian. Journal of Basic and Applied Sciences, Vol 5(8), pp. 258-267.

6. Badcock, B., \& Beer, A. (2000). Home Truths: Property ownership and housing wealth in Australia. Melbourne University Press.

7. Baqutaya, S., Ariffin, A. S., \& Raji, F. (2016). Affordable housing policy: Issues and challenges among middle-income groups. International Journal of Social Science and Humanity, Vol. 6(6), pp. 433-436.

8. Barcus, H. (2004). Urban-rural migration in the USA: An analysis of residential satisfaction. Regional Studies, Vol. 38(6), pp. 643-657.

9. Baron, R. M., \& Kenny, D. A. (1986). The moderator-mediator variable distinction insocial psychological research: Conceptual, strategic and statistical considerations. Journal of Personality and Social Psychology, Vol. 51, pp. 1173-1182.

10.Belsky, E. S., \& Duda, M. (2002). Asset appreciation, timing of purchases and sales, and returns to low-income home ownership. Low-income home ownership: Examining the unexamined goal, Vol. 10(2), pp. 208-238.

11.Bolin, K., Lindgren, B., Lindström, M., \& Nystedt, P. (2003). Investments in social capitalimplications of social interactions for the production of health. Social science \& medicine, Vol. 56(12), pp. 2379-2390. 
12.Borg, I., \& Elizur, D. (1992). Job insecurity: Correlates, moderators and measurement. International Journal of Manpower, Vol. 13(2), pp. 13-26.

13.Campbell, D., \& Sengenberger, W. (1994). Labour standards, economic efficiency and development: lessons from experience with industrial restructuring. International Institute for Labor Studies, Vol. 49(2), 421-39.

14.Chang, S., \& Lee, Z. H. (2013). A study on the influencing effects of university students' e-business start-up intention. The e-Business Studies, 14(3), 37-53.

15.Chen, C. C., Greene, P. G., \& Crick, A. (1998). Does entrepreneurial self-efficacy distinguish entrepreneurs from managers?. Journal of business venturing, 13(4), 295-316.

16.Clark, W., Deurloo, M., \& Dieleman, F. (2006). Residential mobility and neighborhood outcomes. Housing Studies, Vol. 21(3), pp. $323-342$.

17.Collins, B. E., \& Hoyt, M. F. (1972). Personal responsibility-for-consequences: An integration and extension of the "forced compliance" literature. Journal of Experimental Social Psychology, 8(6), 558-593.

18.Cronbach, L. J. (1951). Coefficient alpha and the internal structure of tests. Psychometrika, 16, 297-334.

19.De Beer, S. M. (2011). The psychological contract, job insecurity and the intention to quit of security employees in the Vaal Triangle (Doctoral dissertation, North West University).

20.Der Hovanesian, M. (1999). Spending It, Investing It--Coming on Strong: The Children of the Baby Boomers Are Affecting Spending and Investing as Their Parents Did; The Similarity Ends There. Wall street journal, Eastern edition, 12.

21.DiPasquale, D., \& Glaeser, E. L. (1999). Incentives and social capital: Are home owners better citizens? Journal of urban Economics, Vol. 45(2), pp. 354-384.

22.Dornyei, Z. (2013). Research methods in applied linguistics. New York: Oxford University Press.

23.Evans, G. W., Saltzman, H., \& Cooperman, J. L. (2001). Housing quality and children's socioemotional health. Environment and Behavior, Vol. 33(3), pp. 389-399.

24.Field, A. (2000). Discovering statistics using SPSS for windows, edited. Wright D. London. Thousand Oaks. New.

25.Field, A. (2009). Discovering Statistics Using SPSS: Introducing Statistical Method (3rd ed.). Thousand Oaks, CA: Sage Publications

26.Field, A. (2013). Discovering Statistics using SPSS. Sage: London.

27.Gebel, M. (2010). Early career consequences of temporary employment in Germany and the UK. Work, employment and society, Vol. 24(4), pp. 641-660.

28.Goetzmann, W. N., \& Spiegel, M. I., (2000). The Policy Implications of Portfolio Choice in Underserved Mortgage Markets. SSRN Electronic Journal. Vol. 6(4). pp. 1-39.

29.Goetzmann, W. N. (1993). The single family home in the investment portfolio. The Journal of Real Estate Finance and Economics, Vol. 6(3), pp. 201-222.

30.Griffeth, R. W., Hom, P. W., \& Gaertner, S. (2000). A meta-analysis of antecedents and correlates of employee turnover: Update, moderator tests, and research implications for the next millennium. Journal of management, Vol. 26(3), pp. 463-488. Work, Employment and Society Vol. 24(4), pp. 641-660.

31. Harkness, J. M., and Newman, S. J. (2003) Effects of Home ownership on Children: The Role of Neighborhood Characteristics and Family Income, Economic Policy, Vol. 14(1), pp. 87-107.

32. Haurin D. R., Parcel. T. L., \& Haurin, R. J. (2002). Does home ownership affect child outcomes? Real Estate Economics, Vol. 30(4), pp. 635-666.

33. Hellgren, J., \& Sverke, M. (2003). Does job insecurity lead to impaired well-being or vice versa? Estimation of cross-lagged effects using latent variable modelling. Journal of Organizational Behavior, Vol. 24(2), pp. 215-236.

34. Herbert, C. E., \& Belsky, E. S. (2008). The home ownership experience of low-income and minority households: A review and synthesis of the literature. Vol. 1, pp. 5-59.

35.Hilber, C. A. (2017). The economic implications of house price capitalization: a synthesis. Real Estate Economics, Vol. 45(2), pp. 301-339. 
36. Hulin, C. L., Roznowski, M., \& Hachiya, D. (1985). Alternative opportunities and withdrawal decisions: Empirical and theoretical discrepancies and an integration. Psychological Bulletin, Vol. 97(2), pp. 233-277.

37.Kalleberg, A. L. (2000). Nonstandard employment relations: Part-time, temporary and contract work. Annual review of sociology, Vol. 26(1), pp. 341-365. 436-457.

38.Kan, K. (2007) Residential Mobility and Social Capital, Journal of Urban Economics, Vol. 61, pp.

39.Karsten, L. (2007). Housing as a way of life: Towards an understanding of middle-class families' preference for an urban residential location. Housing Studies, Vol. 22(1), pp. 83-98.

40.Khatri, N., Fern, C. T., \& Budhwar, P. (2001). Explaining employee turnover in an Asian context. Human Resource Management Journal, Vol. 11(1), pp.54-74.

41.Kinnunen, U., Mauno, S., Natti, J., \& Happonen, M. (1999). Perceived job insecurity: A longitudinal study among Finnish employees. European Journal of Work and Organizational Psychology, Vol. 8(2), pp. 243-260.

42.Klug, K. (2017). Young and at risk? Consequences of job insecurity for mental health and satisfaction among labor market entrants with different levels of education. Economic and Industrial Democracy, Vol. 27(2), pp. 223-244.

43.Koe, W. L., Sa'ari, J. R., Majid, I. A., \& Ismail, K. (2012). Determinants of entrepreneurial intention among millennial generation. Procedia-Social and Behavioral Sciences, 40, 197-208.

44.Krejcie, R. V., \& Morgan, D. W. (1970). Determining Sample Size for Research Activities. Educational and Psychological Measurement, 30, 607-610.

45.Kupke, V. (2003). How changes in the labour market have affected first time homebuyers. University of South Australia Library Catalogue. pp. $1445-3428$.

46.Laker, D. R. (2011). Job search, perceptions of alternative employment and turnover. Journal of Applied Business Research (JABR), Vol. 7(1), pp. 6-15.

47.Larson, J. H., Wilson, S. M., \& Beley, R. (1994). The Impact of Job Insecurity on Marital and Family Relationships. Family Relations, Vol. 43 pp. 138-143.

48.Lien, H. M., Wu, W. C., \& Lin, C. C. (2008). New evidence on the link between housing environment and children's educational attainments. Journal of Urban Economics, Vol. 64(2), pp. 408-421.

49.Lim, C. Y. (2013) RPGT can curb speculation in long run. Business Times. Retrieved from,http://www.btimes.com.my/Current_News/BTIMES/articles/20130913120146/20130913120146.pdf

50.Locke, E. (2000). Motivation, cognition, and action: An analysis of studies of task goals and knowledge. Applied Psychology, 49(3), 408-429.

51.Lu, M. (2002). 'Are pastures greener?' Residential consequences of migration. Population, Space and Place, Vol. 8(3), pp. 201-216.

52.MacKinnon, D. P., Fairchild, A. J., \& Fritz, M. S. (2007). Mediation analysis. Annu. Rev. Psychol., Vol. 58, pp. 593-614.

53.Malhotra, N. K. (2004) Marketing Research: An Applied Orientation (4th edition), Pearson Education, Inc: New Jersey. International Journal of Market Research, Vol. 54(6), pp. 835-862.

54.Malhotra, N. K. (2007). Marketing research: an applied approach, 3rd European, Harlow, Prentice Hall/Financial Times

55.Mark, S., Philip, L., \& Adrian, T. (2009). Research methods for business students. An International Journal, Vol. 3(4), pp. 215-218.

56.Masron, T. A., \& Fereidouni, H. G. (2010). Performance and diversification benefits of housing investment in Iran. International Journal of Economics and Finance, Vol. 2(4), pp. 7-11.

57.Mauno, S., \& Kinnunen, U. (1999). Job insecurity and well-being: A longitudinal study among male and female employees in Finland. Community, Work \& Family, Vol. 2(2), pp. 147-171.

58.Mostafa, A., Wong, F. K., \& Hui, C. M. (2006). Relationship between housing affordability and economic development in mainland China-case of Shanghai. Journal of urban planning and development, Vol. 132(1), pp. 62-70.

59.Munch, J. R., Rosholm, M., \& Svarer, M. (2008). Home ownership, job duration, and wages. Journal of Urban Economics, Vol. 63(1), pp. 130-145. 
60.Näswall, K., Sverke, M., \& Hellgren, J. (2005). The moderating role of personality characteristics on the relationship between job insecurity and strain. Work \& Stress, Vol. 19(1), pp. 37-49.

61.Oswald, A. J. (1997). The missing piece of the unemployment puzzle. Perspectives on Labour and Income, Statistics Canada, Vol. 1, pp. 14-24

62.Price, J. L. (2001). Reflections on the determinants of voluntary turnover. International Journal of manpower, Vol. 22(7), pp. 600-624.

63.Queiri, A., Yusoff, W. F. W., \& Dwaikat, N. (2015). Explaining Generation-Y Employees' Turnover in Malaysian Context. Asian Social Science, Vol. 11(10), pp. 126-131.

64.Rabbi, F., Kimiya, F., \& Farrukh, M. (2015). The Impact of Job Satisfaction, Perceived Availability of Job Alternative on Turnover Intention. Journal for Studies in Management and Planning, Vol. 1(11), pp. 319328.

65.Rohe, W. M., \& Stegman, M. A. (1994). The effects of homeownership: On the self-esteem, perceived control and life satisfaction of low-income people. Journal of the American Planning Association, Vol. 60(2), pp. 173-184.

66.Rohe, W. M., \& Stewart, L. S. (1996). Homeownership and neighborhood stability. Housing Policy Debate, Vol. 7(1), pp. 37-81.

67.Rohe, W. M., Van Zandt, S., \& McCarthy, G. (2013). The social benefits and costs of homeownership: A critical assessment of the research. The affordable housing reader, Vol. 40, pp. 196-213.

68.Rojanasarot, S., Gaither, C. A., Schommer, J. C., Doucette, W. R., Kreling, D. H., \& Mott, D. A. (2017). Exploring pharmacists' perceived job alternatives: Results from the 2014 National Pharmacist Workforce Survey. Journal of the American Pharmacists Association, Vol. 57(1), pp. 47-55.

69.Rossi, P. H., \& Weber, E. (1996). The social benefits of homeownership: Empirical evidence from national surveys. Housing policy debate, Vol. 7(1), pp. 1-35.

70.Saiz, A. (2010). The geographic determinants of housing supply. The Quarterly Journal of Economics, Vol. 125(3), pp. 1253-1296.

71.Salleh, A. G. (2008). Neighbourhood factors in private low-cost housing in Malaysia. Habitat International, Vol. 32(4), pp. 485-493.

72.Savasdisara, T., Tips, W. E., \& Suwannodom, S. (1989). Residential satisfaction in private estates in Bangkok: A comparison of low-cost housing estates and determinant factors*. Habitat International, Vol. 13(1), pp. 65-73.

73.Scarpetta, S., Sonnet, A., \& Manfredi, T. (2010). Rising youth unemployment during the crisis. OECD Social, Employment and Migration Working Papers.

74.Sheahan, P. (2008). Generation-Y In Asia. Sydney: The University of Sydney.

75.Tabachnick, B. G. \& Fidell, L. S. (2014). Using multivariate statistics (6th edition). Boston, MA: Pearson.

76.Tan, T. H. (2008) Determinants of Homeownership in Malaysia. Habitat International, Vol. 32(3), pp. 318-335.

77.Tan, T. H., \& Khong, K. W. (2012). The link between homeownership motivation and housing satisfaction. International Journal of Economic and Management, Vol. 6 (1), pp. 1 -12.

78.Thompson, B. (2004). Exploratory and confirmatory factor analysis: Understanding concepts and applications. Applied Psychological Measurement, Vol. 31(3), pp. 245-248.

79.Treuren, G. (2013). The Relationship Between Perceived Job Alterntives, Employee Attitudes and Leaving Intention (Doctoral dissertation, ANZAM-Australian and New Zealand Academy of Management).

80.Vera-Toscano, E., \& Ateca-Amestoy, V. (2008). The relevance of social interactions on housing satisfaction. Social Indicators Research, Vol. 86(2), pp. 257-274.

81.Westlund, H. (2006). Social capital in the knowledge economy: Theory and empirics. Springer Science \& Business Media. Journal of Regional Science, Vol. 48(3), pp. 675-677.

82. Witte, H. D. (1999). Job insecurity and psychological well-being: Review of the literature and exploration of some unresolved issues. European Journal of work and Organizational psychology, Vol. 8(2), pp. 155-177.

83.Wolfer, L. (2007). Real Research: Conducting and Evaluating Research in the Social Sciences. Boston: Pearson/Allyn and Bacon 
84.Yun, L., \& Evangelou, N. (2016). Social Benefits of Homeownership and Stable Housing. National Assciation of Realtor, Vol.(5), pp. 2-19.

85.Yusof, M., Sandhu, M. S., \& Jain, K. K. (2007). Relationship between psychological characteristics and entrepreneurial inclination: A case study of students at University Tun Abdul Razak (Unitar). Journal of Asia Entrepreneurship and sustainability, 3(2), 23-41.

86.Yusoff, W. T. W., Mat, C. R. C., \& Zainol, R. M. (2017). Predictors and consequences of job insecurity: A preliminary study of Malaysian bank employees. Geografia-Malaysian Journal of Society and Space, Vol. 10(3), pp. 8-13

87.Yusoff, W. W., Queiri, A., Zakaria, S., \& Hisham, R. (2013). Generation-Y Turnover Asian Social Science, Vol. 11(10), pp.

88.Yusuf, A., \& Resosudarmo, B. (2009). Does clean air matter in developing countries' megacities? A hedonic price analysis of the Jakarta housing market. Indonesia' Ecological Economics, Vol. 68, pp. 13981407. 